УДК 634.8.04

DOI 10.30679/2219-5335-2019-6-60-51-59

СОХРАНЕНИЕ ГЕНОФОНДА

ВИНОГРАДА НА АНАПСКОЙ АМПЕЛОГРАФИЧЕСКОЙ КОЛЛЕКЦИИ

Лукьянова Анна Александровна канд. биол. наук научный сотрудник

лаборатории виноградарства и виноделия

Горбунов Иван Викторович

канд. биол. наук

научный сотрудник

лаборатории виноградарства и виноделия

Лукьянов Алексей Александрович

канд. с.-х. наук

старший научный сотрудник

директор АЗОСВиВ

Анапская зональная опытная станция виноградарства и виноделия филиал Федерального государственного бюджетного научного учреждения «Северо-Кавказский федеральный научный иентр садоводства, виноградарства, виноделия», Анапа, Россия

Петров Валерий Семенович д-р с.-х. наук зав. функциональным научным центром «Виноградарство и виноделие»

Федеральное государственное бюджетное научное учреждение «Северо-Кавказский федеральньй научный ичентр садоводства, виноградарства, виноделия», Краснодар, Россия

В данной статье представлен анализ генетических ресурсов винограда на мировом и российском уровнях. Во многих странах мира разрабатываются и реализуются
UDC 634.8.04

DOI 10.30679/2219-5335-2019-6-60-51-59

\section{GRAPE GENEPOOL CONSERVATION \\ OF ANAPA AMPELOGRAPHIC COLLECTION}

Lukyanova Anna Aleksandrovna

Cand. Biol. Sci.

Research Associate

of Viticulture and Winemaking Laboratory

Gorbunov Ivan Viktorovich

Cand. Sci. Biol.

Research Associate

of Viticulture and Winemaking Laboratory

Lukyanov Aleksey Aleksandrovich

Cand. Agr. Sci.

Senior Research Associate

Chief of AZESVW

Anapa Zonal Experimental Station

of Viticulture and Winemaking -

Branch of Federal State

Budgetary Scientific Institution

"North-Caucasus Federal

Scientific Center of Horticulture,

Viticulture, Winemaking»,

Anapa, Russia

Petrov Valeriy Semionovih

Dr. Sci. Agr.

Head of the Functional Scientific Center

«Viticulture and Wine-making»

Federal State Budget

Scientific Institution

"North Caucasian Federal

Scientific Center of Horticulture,

Viticulture, Wine-making»,

Krasnodar, Russia

This article presents an analysis

of the grape genetic resources

at the global and Russian levels.

In many countries of the world, 
национальные программы по сохранению и использованию генетических ресурсов растений. В работе дана информация по формированию единых подходов к использованию существующих биоресурсных коллекций России и созданию единой информационной системы. Кроме того, показаны результаты работы по сохранению генофонда винограда на Анапской опытной станции виноградарства и виноделия за последние два года. Приведён сравнительный анализ по количественному соотношению сортообразцов винограда, произрастающих в иных ампелографических коллекциях. В частности, по числу образцов Анапская ампелографическая коллекция является самой крупной коллекцией винограда в России, в которой произрастают образцы из тридцати двух коллекций, относящихся к восемнадцати государствам мира. Каждый год коллекция пополнятся в среднем на десять сортообразцов. Комплексное их изучение необходимо для выявления закономерностей адаптивных реакций сортов винограда различного эколого-географического происхождения на изменяющиеся условия вегетационного периода и выделения доноров и источников селекционно-ценных признаков для использования в селекции. Так как сохранение коллекционного генофонда винограда представляет определённую трудность в связи с различной адаптивной способностью сортов, оказавшихся в других почвенноклиматических условиях, отличающихся от условий прежнего произрастания. В связи с этим в данной статье указывается информация о перезакладке самой крупной в России ампелографической коллекции, в которой планируется пополнение генофонда винограда кубанскими дикорастущими формами, интересными в селекционном плане.

Ключевые слова: ГЕНОФОНД, СОРТ, ВИНОГРАД, ГЕНЕТИЧЕСКИЕ РЕСУРСЫ, АМПЕЛОГРАФИЧЕСКАЯ КОЛЛЕКЦИЯ the national programs for the conservation and use of plant genetic resources are developed and implemented. The work provides the information on the formation of common approaches to the use of existing bioresource collections in Russia and the creation of a unified information system. In addition, the results of the work on preserving the gene pool of grapes at the Anapa experimental station of viticulture and winemaking over the past two years are shown. A comparative analysis of the quantitative ratio of grape varieties growing in the other ampelographic collections is given. In particular, according to the number of samples, the Anapa ampelographic collection is the largest collection of grapes in Russia, in which there are the samples from thirty-two collections belonging to eighteen states of the world.

Every year, the collection is replenished with an average of ten varieties.

A comprehensive study of them is necessary to identify the patterns of adaptive reactions of grape varieties of various ecological and geographical origin to changing conditions of the growing season and the selection of donors and sources of breeding-valuable traits for use in the breeding. That is the preservation of the collect grape gene pool is a certain difficulty in connection with the different adaptive ability of the varieties under the other soil and climatic conditions that differ from the conditions of the previous cultivation. In this regard, this article provides the information on the relaying of the largest ampelographic collection in Russia, in which it is planned to replenish the gene pool of grapes with Kuban wild-growing forms that are of interest in the breeding.

Key words: GENE POOL, VARIETY, GRAPES, GENETIC RESOURCES, AMPELOGRAPHIC COLLECTION 
Введение. Изучение и сохранение генетического разнообразия являются одними из важных фундаментальных научных задач в генетике культурных растений [1-6]. Во многих странах мира разрабатываются и реализуются национальные программы по сохранению и использованию генетических ресурсов растений [7-9]. На портале Genesys (https://www.genesyspgr.org) представлена информация о генетических ресурсах 252 стран, 435 научных организаций - всего описано около 3617263 растений, в том числе 38140 образцов рода Vitis. Россия в проекте Genesys представлена ВИР им. Н.И. Вавилова (200157 образцов, входит в сеть EURISCO).

Bce данные проекта Genesys включают в себя портал Global Biodiversity Information Facility (https://www.gbif.org/) (GBIF), работающий по принципу открытого участия. Он собрал в себе 965,729,825 записей о различных образцах в генетических коллекциях по всему миру, в том числе 127763 записи об образцах из 287 разновидностей (включая подвиды, межвидовые гибриды) рода Vitis, из них Vitis vinifera - 71246 записей, а к 5418 записям прилагаются фотографии.

В 2018 году в нашей стране в целях развития научной инфраструктуры Федеральное агентство научных организаций провело работу по формированию единых подходов к использованию существующих биоресурсных коллекций России и созданию единой информационной системы [10]. Так была создана информационная система «Биоресурсные коллекции научных организаций» в виде интернет-портала (www.biores.cytogen.ru). На данном портале зарегистрированы 4 ампелографические коллекции (Ампелографическая коллекция «Магарач», Анапская ампелографическая коллекция, Донская ампелографическая коллекция имени Я.И. Потапенко, Ампелографическая коллекция ДСОСВиО), в которых ведутся работы по изучению, сохранению генетического разнообразия и формированию баз данных сортов винограда [11-17]. Количественное соотношение соротообразцов винограда, произрастающих в вышеупомянутых коллекциях, по данным интернет-портала (www.biores.cytogen.ru), представлено на рисунке 1. 


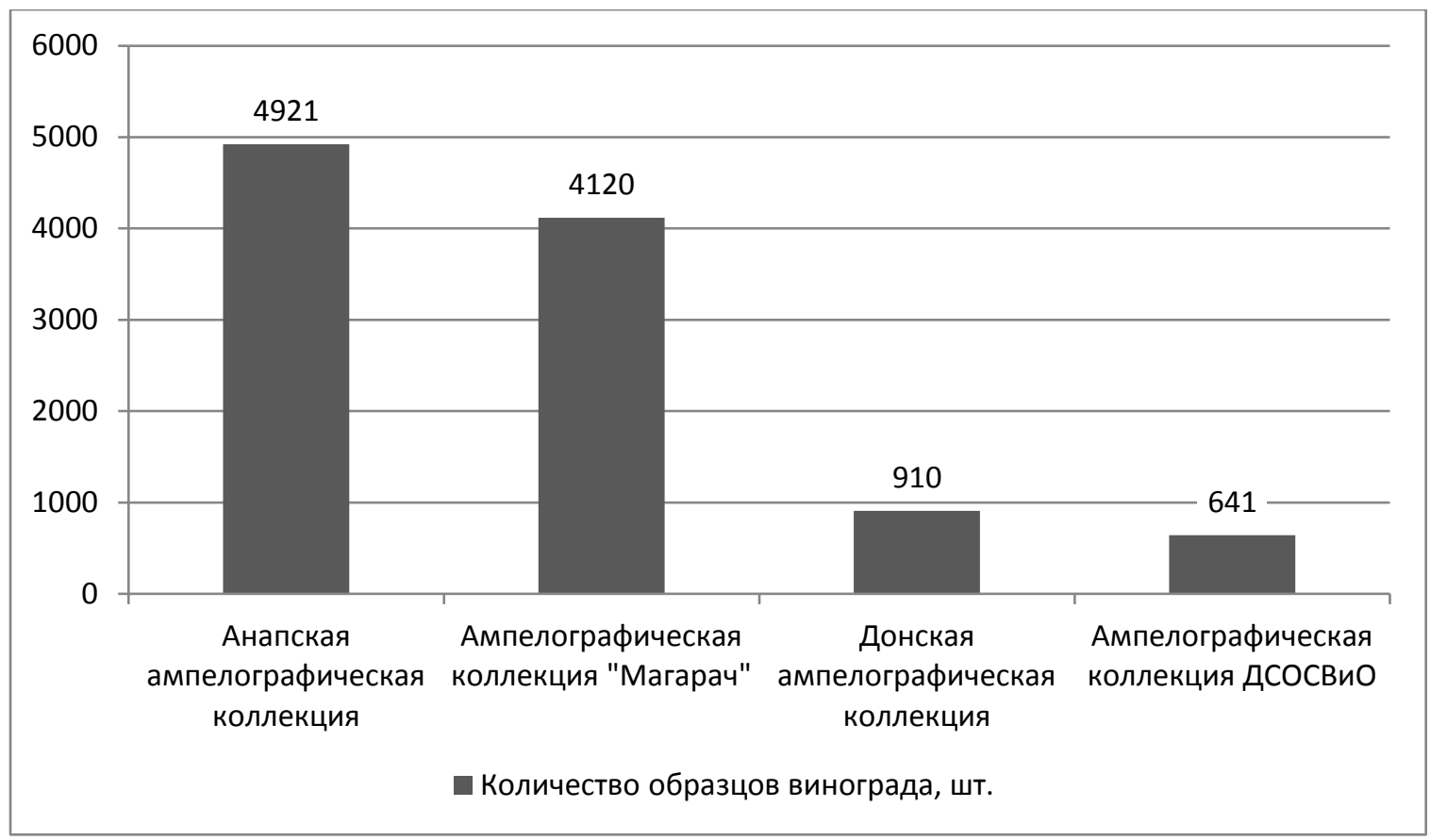

Рис. 1 Количественное соотношение сортообразцов винограда среди держателей коллекций России (по данным интернет-портала (www.biores.cytogen.ru))

Обсужљение результатов. Ампелографические коллекции обеспечивают сбор, хранение и комплексный анализ данных о генофонде винограда, что является определяющим условием устойчивого развития отрасли виноградарства в России. По числу образцов Анапская ампелографическая коллекция является самой крупной коллекцией винограда России. В ней собраны образцы из 32 коллекций 18 государств [18].

Ежегодно Анапская коллекция пополнятся в среднем на 10 сортообразцов. В период 2017-2019 гг. коллекция была пополнена следующими сортами винограда: Памяти Судоплатова, Спецназ, Димон белый, Теремной, Престиж, Ванесса сидлис, Гленора сидлис, Ремейли сидлис, Эйнсет сидлис, Преображение, Юбилей одесского СХИ, Гармония, Престиж, Сатурн, Фиалковый, Марсело, Фуршетный, Симпатия, Преображение, Заря Несветая, Ромео, Юбилей херсонского дачника, Каберне Карменер и др.

На сегодняшний день в Анапской ампелографической коллекции произрастает 4941 сортообразец винограда. Коллекция заложена 
в 1997-2009 гг. и состоит из привитой части и корнесобственной. Площадь коллекционного участка составляет 17,5 га. Привитая часть, расположенная на площади 8,05 га, в свою очередь разделена на два участка - со столовыми сортами винограда (3,82 га) и техническими (4,23 га). Видовой и генетический состав генофонда Анапской ампелографической коллекции представлен в таблице 1.

Таблица 1 - Видовой и генетический состав генофонда Анапской ампелографической коллекции

\begin{tabular}{|l|c|c|}
\hline \multicolumn{1}{|c|}{ Виды, генетические группы } & \multicolumn{2}{c|}{ Количество образцов } \\
\cline { 2 - 3 } & шт. & $\%$ \\
\hline 1. Сорта Vitis vinifera L. & 2980 & 60,4 \\
\hline - местные & 2120 & 43,0 \\
\hline - гибридизированные & 859 & 17,4 \\
\hline 2. Сорта других видов Vitis L., в т.ч. & 90 & 1,8 \\
\hline - V. aтитеnsis Rupr. & 40 & 0,8 \\
\hline - V. labrusca L. & 50 & 1,0 \\
\hline 3. Межвидовые copта, в т.ч. & 950 & 19,2 \\
\hline - Vitis vinifera L. х V. amurensis Rupr. & 210 & 4,3 \\
\hline - Vitis vinifera L. х V. labrusca L. & 172 & 3,5 \\
\hline - Vitis vinifera L. х гиб. SV & 220 & 4,5 \\
\hline - Vitis vinifera L. х V. aтитеnsis Rupr. х гиб. SV & 72 & 1,5 \\
\hline - комбинации скрещиваний неизвестных видов & 275 & 5,6 \\
\hline 4. Неизвестного происхождения & 400 & 8,1 \\
\hline 5. Другие образцы (клоновая селекция, гибридные и дикорас- \\
тущие формы и пр.) & 521 & 10,5 \\
\hline Итого: & 4941 & 100 \\
\hline
\end{tabular}

По видовому составу в собранном генофонде доминируют сорта V. vinifera L., что составляет три четверти генофонда. По направлению использования доминируют столовые сорта (3162 сортообразцов), технические сорта представлены 1726 сортообразцами, довольно полно представлены сорта-подвои - 53 [19].

Сохранение коллекционного генофонда винограда представляет определенную трудность в связи с различной адаптивной способностью сортов, оказавшихся в других почвенно-климатических условиях, отличающихся от условий прежнего произрастания. Именно поэтому в 2017 году научными сотрудниками АЗОСВиВ-филиала ФГБНУ СКФНЦСВВ сов- 
Плодоводство и виноградарство Юга России № 60(06), 2019 г.

местно с ФГБНУ Северо-Кавказским федеральным научным центром садоводства, виноградарства, виноделия начата работа по перезакладке ампелографической коллекции, которая будет проводиться ежегодно. Основанием для этого послужил приказ директора ФГБНУ СКЗНИИСиВ №28 от 10 марта 2017 года.

Во исполнение этого приказа была активизирована работа по апробации, заготовке черенкового материала с последующим производством привитых саженцев. В 2018 году были произведены привитые саженцы 219 сортов винограда. Распределение посадочного материала по направлению использования и срокам созревания сортов винограда представлено в таблице 2. Весной 2019 года произведена посадка растений на постоянное место - в новый коллекционный участок.

Таблица 2 - Распределение посадочного материала по направлению использования и срокам созревания сортов винограда

\begin{tabular}{|l|c|c|c|c|}
\hline \multicolumn{1}{|c|}{ Срок созревания } & Столовые & Технические & Универсальные & Итого \\
\hline Сверхранний & 6 & & & 6 \\
\hline Очень ранний & 22 & & 1 & 23 \\
\hline Ранний & 45 & 5 & 1 & 55 \\
\hline Раннесредний & 13 & 8 & 3 & 22 \\
\hline Средний & 16 & 21 & 1 & 31 \\
\hline Среднепоздний & 10 & 20 & 3 & 40 \\
\hline Поздний & 13 & 24 & & 2 \\
\hline Очень поздний & 2 & & $\mathbf{1 4}$ & $\mathbf{2 1 9}$ \\
\hline Общий итог & $\mathbf{1 2 7}$ & $\mathbf{7 8}$ & & \\
\hline
\end{tabular}

Новый участок ампелографической коллекции, так же как и основной, относится к Северо-Западной Кавказской горной провинции [18]. Почва участка - чернозем южный, слабовыщелоченный, сформированный на элювии плотных песчаников и карбонатных сланцев. Общая площадь нового участка составляет 20 га, схема посадки $3 \times 1,5$ м по 10 растений каждого сорта. Все сортообразцы возделываются в привитой культуре на подвое Кобер 5ББ. 
Плодоводство и виноградарство Юга России № 60(06), 2019 г.

Заключение. Перезакладка ампелографической коллекции - работа очень кропотливая и долгая, все сорта, произрастающие на прежнем участке, как на участке накопления, так и в привитой части коллекции, будут планомерно перенесены на новый участок. В дальнейшем планируется пополнение генофонда винограда кубанскими дикорастущими формами, интересными в селекционном плане [20]. Они будут использованы как доноры устойчивости к биотическим и абиотическим факторам среды.

\section{Литература}

1. Saniya, Kanwar, J., Naruka, I.S., Singh, P.P. Genetic variability and association among colour and white seedless genotypes of grape (Vitis vinifera) // Indian Journal of Agricultural Sciences. 2018; 88(5): 737-745.

2. Alba V., Bergamini C., Genghi R. et al. Ampelometric Leaf Trait and SSR Loci Selection for a Multivariate Statistical Approach in Vitis vinifera L. Biodiversity Management // Mol Biotechnol. 2015; 57: 709. https://doi.org/10.1007/s12033-015-9862-5

3. Failla, O. East -West collaboration for grapevine diversity exploration and mobilization of adaptive traits for breeding: A four years story Vitis - Journal of Grapevine Research 2015; 54: 1-4.

4. Maletić, E., Pejić, I., Karoglan Kontić, J. et al. Ampelographic and genetic characterization of Croatian grapevine varieties // Vitis - Journal of Grapevine Research 2015; 54(Special Issue): 93-98.

5. Petrov V.S., Aleinikova G.Yu., Naumova L.G., Lukyanova A.A. Adaptive reaction of grape varieties in conditions of climate change // Лозарство и винарство. 2018; 6: 18-31.

6. Zoghlami, N., Riahi, L., Laucou, V., et al. Genetic structure of endangered wild grapevine Vitis vinifera ssp. sylvestris populations from Tunisia: Implications for conservation and management // Forest Ecology and Management. 2013; 310: 896-902.

7. Eibach, R., Töpfer, R. Traditional grapevine breeding techniques (Book Chapter) // Grapevine Breeding Programs for the Wine Industry 2015 c. 1-22

8. Marrano, A., Grzeskowiak, L., Moreno Sanz, P., Maghradze, D., Grando, M.S. Genetic diversity and relationships in the grapevine germplasm collection from Central Asia Vitis - Journal of Grapevine Research 54(Special Issue),2015 c. 233-237

9. Aradhya, M.K., Preece, J., Kluepfel, D.A. Genetic conservation, characterization and utilization of wild relatives of fruit and nut crops at the USDA germplasm repository in Davis, California // Special Paper of the Geological Society of America 2015; 1074: 95-104.

10. , Информационная система по биоресурсным коллекциям институтов ФАНО России / С.А. Лашин и др. // Вавиловский журнал генетики и селекции. 2018; 22(3): 386-393. DOI 10.18699/VJ18.360.

11. Наумова Л.Г., Ганич В.А. Мобилизация и сохранение генетического разнообразия сортов винограда на коллекции ВНИИВИВ им. Я.И. Потапенко // Русский виноград. 2017. Т. 5. С. 40-46.

12. Полулях А.А., Волынкин В.А., Лиховской В.В. Генетические ресурсы винограда института «Магарач». Проблемы и перспективы сохранения // Вавиловский журнал генетики и селекции. 2017; 21(6):608-616. DOI 10.18699/VJ17.276. 
13. Анапская ампелографическая коллекция - крупнейший центр аккумуляции и изучения генофонда винограда в России / М.И. Панкин, В.С. Петров, А.А. Лукьянова, Е.Т. Ильницкая и др. // Вавиловский журнал генетики и селекции. 2018; 22(1):54-59. DOI 10.18699/VJ18.331.

14. Лукьянов А. А., Большаков В. А., Ильницкая Е. Т. Создание базы данных и ДНК-паспортизация сортов Анапской ампелографической коллекции [Электронный ресурс] // Плодоводство и виноградарство Юга России. 2018. № 51(3). С. 50-59. URL: http://journalkubansad.ru/pdf/18/03/05.pdf. DOI: 10.30679/2219-5335-2018-3-51-50-59 (дата обращения: 22.10.2019).

15. Лукьянова А.А., Большаков В.А. Цифровые инструменты для сбора, обобщения и анализа первичной информации Анапской ампелографической коллекции // Научные труды СКФНЦСВВ. Т. 24. Краснодар: СКФНЦСВВ, 2019. С. 38-40.

16. Новикова Л.Ю., Наумова Л.Г. Структурирование ампелографической коллекции по фенотипическим характеристикам и сравнение реакции сортов винограда на изменение климата Вавиловский журнал генетики и селекции. 2019. Т. 23. № 6. C. $142-149$.

17. Горбунов И. В., Коваленко А. Г., Разживина Ю. А. Анализ сортового состава винограда по срокам созревания в ампелографической коллекции Анапской зональной опытной станции виноградарства и виноделия [Электронный ресурс] // Плодоводство и виноградарство Юга России. 2019. № 57(3). С. 51-59. URL: http://journalkubansad.ru/pdf/19/03/04.pdf. DOI: 10.30679/2219-5335-2019-3-57-51-59 (дата обращения: 22.10.2019).

18. Анапская ампелографическая коллекция (Биологические растительные ресурсы): монография / Егоров Е.А., Ильина И.А., Петров В.С. и др. Краснодар, 2018. $194 \mathrm{c}$.

19. Большаков В.А., Панкин М.И., Петров В.С. и др. База данных сортов винограда анапской ампелографической коллекции: Свидетельство о регистрации базы данных RUS 2018620901 07.05.2018

20. Горбунов И.В. Дикорастущий виноград, как основа перспективной селекционной работы // Сборник трудов международной конференции «Современному АПК эффективные технологии». Ижевск: Ижевская ГСХА, 2019. С. 114-116.

\section{References}

1. Saniya, Kanwar, J., Naruka, I.S., Singh, P.P. Genetic variability and association among colour and white seedless genotypes of grape (Vitis vinifera) // Indian Journal of Agricultural Sciences. 2018; 88(5): 737-745.

2. Alba V., Bergamini C., Genghi R. et al. Ampelometric Leaf Trait and SSR Loci Selection for a Multivariate Statistical Approach in Vitis vinifera L. Biodiversity Management // Mol Biotechnol. 2015; 57: 709. https://doi.org/10.1007/s12033-015-9862-5

3. Failla, O. East -West collaboration for grapevine diversity exploration and mobilization of adaptive traits for breeding: A four years story Vitis - Journal of Grapevine Research 2015; 54: 1-4.

4. Maletić, E., Pejić, I., Karoglan Kontić, J. et al. Ampelographic and genetic characterization of Croatian grapevine varieties // Vitis - Journal of Grapevine Research 2015; 54(Special Issue): 93-98.

5. Petrov V.S., Aleinikova G.Yu., Naumova L.G., Lukyanova A.A. Adaptive reaction of grape varieties in conditions of climate change // Lozarstvo i vinarstvo. 2018; 6: 18-31.

6. Zoghlami, N., Riahi, L., Laucou, V., et al. Genetic structure of endangered wild grapevine Vitis vinifera ssp. sylvestris populations from Tunisia: Implications for conservation and management // Forest Ecology and Management. 2013; 310: 896-902. 
7. Eibach, R., Töpfer, R. Traditional grapevine breeding techniques (Book Chapter) // Grapevine Breeding Programs for the Wine Industry 2015 s. 1-22

8. Marrano, A., Grzeskowiak, L., Moreno Sanz, P., Maghradze, D., Grando, M.S. Genetic diversity and relationships in the grapevine germplasm collection from Central Asia Vitis - Journal of Grapevine Research 54(Special Issue),2015 s. 233-237

9. Aradhya, M.K., Preece, J., Kluepfel, D.A. Genetic conservation, characterization and utilization of wild relatives of fruit and nut crops at the USDA germplasm repository in Davis, California // Special Paper of the Geological Society of America 2015; 1074: 95-104.

10. , Informacionnaya sistema po bioresursnym kollekciyam institutov FANO Rossii / S.A. Lashin i dr. // Vavilovskij zhurnal genetiki i selekcii. 2018; 22(3): 386-393. DOI 10.18699/VJ18.360.

11. Naumova L.G., Ganich V.A. Mobilizaciya i sohranenie geneticheskogo raznoobraziya sortov vinograda na kollekcii VNIIVIV im. Ya.I. Potapenko // Russkij vinograd. 2017. T. 5. S. 40-46.

12. Polulyah A.A., Volynkin V.A., Lihovskoj V.V. Geneticheskie resursy vinograda instituta «Magarach». Problemy i perspektivy sohraneniya // Vavilovskij zhurnal genetiki i selekcii. 2017; 21(6):608-616. DOI 10.18699/VJ17.276.

13. Anapskaya ampelograficheskaya kollekciya - krupnejshij centr akkumulyacii i izucheniya genofonda vinograda v Rossii / M.I. Pankin, V.S. Petrov, A.A. Luk'yanova, E.T. Il'nickaya i dr. // Vavilovskij zhurnal genetiki i selekcii. 2018; 22(1):54-59. DOI 10.18699/VJ18.331.

14. Luk'yanov A. A., Bol'shakov V. A., Il'nickaya E. T. Sozdanie bazy dannyh i DNK-pasportizaciya sortov Anapskoj ampelograficheskoj kollekcii [Elektronnyj resurs] // Plodovodstvo i vinogradarstvo Yuga Rossii. 2018. № 51(3). S. 50-59. URL: http://journalkubansad.ru/pdf/18/03/05.pdf. DOI: 10.30679/2219-5335-2018-3-51-50-59 (data obrashcheniya: 22.10.2019).

15. Luk'yanova A.A., Bol'shakov V.A. Cifrovye instrumenty dlya sbora, obobshcheniya i analiza pervichnoj informacii Anapskoj ampelograficheskoj kollekcii // Nauchnye trudy SKFNCSVV. T. 24. Krasnodar: SKFNCSVV, 2019. S. 38-40.

16. Novikova L.Yu., Naumova L.G. Strukturirovanie ampelograficheskoj kollekcii po fenotipicheskim harakteristikam i sravnenie reakcii sortov vinograda na izmenenie klimata Vavilovskij zhurnal genetiki i selekcii. 2019. T. 23. № 6. S. 142-149.

17. Gorbunov I. V., Kovalenko A. G., Razzhivina Yu. A. Analiz sortovogo sostava vinograda po srokam sozrevaniya $v$ ampelograficheskoj kollekcii Anapskoj zonal'noj opytnoj stancii vinogradarstva i vinodeliya [Elektronnyj resurs] // Plodovodstvo i vinogradarstvo Yuga Rossii. 2019. № 57(3). S. 51-59. URL: http://journalkubansad.ru/pdf/19/03/04.pdf. DOI: 10.30679/2219-5335-2019-3-57-51-59 (data obrashcheniya: 22.10.2019).

18. Anapskaya ampelograficheskaya kollekciya (Biologicheskie rastitel'nye resursy): monografiya / Egorov E.A., Il'ina I.A., Petrov V.S. i dr. Krasnodar, 2018. 194 s.

19. Bol'shakov V.A., Pankin M.I., Petrov V.S. i dr. Baza dannyh sortov vinograda anapskoj ampelograficheskoj kollekcii: Svidetel'stvo o registracii bazy dannyh RUS 2018620901 07.05.2018

20. Gorbunov I.V. Dikorastushchij vinograd, kak osnova perspektivnoj selekcionnoj raboty // Sbornik trudov mezhdunarodnoj konferencii «Sovremennomu APK effektivnye tekhnologii». Izhevsk: Izhevskaya GSHA, 2019. S. 114-116. 